\title{
“İçimizdeki Şeytan”a yenilmeyen Macide’nin toplumsal cinsiyet açısından düşündürdü̈kleri
}

\section{Aziz ŞEKER ${ }^{1}$}

APA: Şeker, A. (2020). “İçimizdeki Şeytan”a yenilmeyen Macide’nin toplumsal cinsiyet açısından düşündürdükleri. RumeliDE Dil ve Edebiyat Araşttrmaları Dergisi, (19), 297-308. DOI: 10.29000/rumelide.752346.

\section{Öz}

Roman, edebiyat sosyolojisi açısından başlı başına sosyal bir olgudur. Roman türleri içerisinde özellikle gerçekçi roman; konuları ve roman karakterleri yönüyle toplumsal yapıyı yansıtacak birçok unsura sahiptir. Çağdaş Türk edebiyatında gerçekçi romanlarıyla yer etmiş bir yazar olarak Sabahattin Ali'nin, toplumla ilgili sosyal konuları işleyen romanları; yazıldığı dönemin toplumuna, bireylerine, insan ilişkilerine, toplumsal cinsiyet kurulumuna ve ataerkil kültürüne ilişkin çok sayıda önemli veri içerir. Bu verilerden yola çıkarak yapılacak çözümlemeler, romanın yazıldı̆̆ı topluma dair bir bellek oluşturabileceğini de gösterir. Bu çalışmada Sabahattin Ali’nin İçimizdeki Şeytan yapıtında, roman karakteri Macide odağa alınarak, toplumsal cinsiyet temelinde kadın temsili analiz edilecektir. Romanda ana karakterler içinde bir kadının temsil düzeyini incelemenin kadının toplumdaki durumunu değerlendirmeye katkı sağlayacağı düşünülmektedir.

Anahtar kelimeler: Sabahattin Ali, toplumsal cinsiyet, roman, Macide, sosyoloji

\section{What Macide, who was not beaten by "İçimizdeki Şeytan" (The Devil inside Us) make us think in terms of gender}

\begin{abstract}
Novel is a social phenomenon in itself in terms of the sociology of literature. Especially realist novel among novel genres has many characteristics which reflect the social structure in terms of subjects and novel characters. Sabahattin Ali, a writer who attained an important place with his realist novels in contemporary Turkish literature, wrote many novels about social issues. His novels contain a lot of important data about the society, individuals, human relations, gender and patriarchal culture of the period when they were written. Analyzes based on these data also shows that the novel can create a memory of the society in which it is written. In this study, we will analyze the female representation in terms of gender through a focus on Macide, the female protagonist of Sabahattin Ali's "İçimizdeki Şeytan”. Analyzing the level of representation of a woman within the main characters is thought to contribute to our assessment of the status of women in society.
\end{abstract}

Keywords: Sabahattin Ali, gender, novel, Macide, sociology

\section{Giriş}

Sabahattin Ali, 1940 kuşağının önde gelen yazarları arasında yer alır. Yazdıklarıyla toplum eleştirisi yapan yazar, toplumsal eşitsizliklerin bireylere yansıdığı alanları işlerken sorun odaklı dinamik bir roman anlayışından yola çıkar. İnsanların içinde yer aldığı olaylar ve durumlar, toplumsal cinsiyet

Dr. Amasya Üniversitesi (Amasya, Türkiye), shuaziz@gmail.com, ORCID ID: oooo-0oo1-5634-0221 [Makale kayıt tarihi: 13.02.2020-kabul tarihi: 20.06.2020; DOI: 10.29000/rumelide.752346] 
eşitsizliğinin her yönüyle hüküm sürdüğü bir sosyal yapıda kadın kimliğinin eşit olmadığı erkek egemen bir kültür inşa eder. Sabahattin Ali, kadının özgür olmadığı erkek egemen toplumsal yapıda, romanlarını adalet, eşitlik gibi insancıl değerlerin önemsendiği felsefi bir temel üzerine kurar. Bununla birlikte Sabahattin Ali'nin toplumcu bir dünya görüşüne sahip olması yapıtlarında da karşllı̆̆ını bulur. Ancak bu anlamda roman kahramanlarına kaba ideolojik özellikler yüklemez. Sabahattin Ali, yazıları ve politik tutumu nedeniyle egemen olanın hışmına uğradığı bir zaman diliminde üretken bir yazar olarak çok genç yaşta öldürülür. Sabahattin Ali dünyanın eşit ve adil olması gerektiği yönündeki düşüncelerinden hareketle, gelecek kuşak yazarlarına ve okurlara her dönem yapitlarının tartışlacağı bir miras bırakmıştır.

Sabahattin Ali'nin İçimizdeki Şeytan (1940) romanı, bir aşk ilişkisi etrafında kurgulanırken sosyolojik bağlamda dönemin İstanbul'unda bir grup aydının yaşamından kesitler vermesi yönüyle de önemli bir içeriğe sahiptir. Korkmaz’a göre, İçimizdeki Şeytan, "roman kahramanı Ömer’in ferdî plandaki tezatları ve buhranları üzerine kurulmasına rağmen, toplumsal yanı ağır basan eleştirel gerçekçi bir romandır. Yazar, 1930-1940'ların Türkiye'sindeki aydın ve entellektüel kesimin ideolojik açıdan değerlendirilmesine olanak sağlar. Bu yüzden yayımlandığı zaman uyandırdığı geniş akisler, onun edebi yönden çok siyasi ve ideolojik yönüne ait değerlendirmeleri kapsamıştır” (1991, s. 226). Ayrıca tarih olarak Anadolu toplumsal yapısında Cumhuriyet kavramının henüz sindirilememişliği, hayata getirdiği yeniliklere adapte olamayan halkın uyum sağlama çabaları, toplumda meydana gelen aydın ve geri kalmış Anadolu ayrımı, romanda belirli karakterler aracılığıyla verilmeye çalışılmıştır (Tanrıkulu, 2018, s. 29).

Romanın toplumsal cinsiyet hiyerarşisinin hüküm sürdüğü toplumsal koşulları görmek adına birçok ögeyi barındırdığını söylemek mümkündür. Örneğin kamusal alanda kadınlar, sosyal statülerine dair çıkarımlar yapıldığında görece ileri denilebilecek bazı özellikler taşımaktadır. Romanın ilk kısımlarında, Balıkesir'de karma eğitim yapıldığını ve kızların eğitim öğretim hizmetlerinden yararlandığı bilgisi verilir. Ne var ki romanda, kadın karakterler üzerinden gidildiğinde eğitim yoluyla kadınların toplum içinde nasıl yükseldikleri ya da eğitimin kadınların sosyal statülerine etkisinin tam anlamıyla işlenmediği görülür. Bir insan hakkı kabul edilen kadının eğitim hakkının olduğu ve yeri geldiğinde eğitim hakkından yararlanmasına dair düzenlemeler Cumhuriyetin kuruluş aşamasından sonra tek partinin toplumu dönüştürme reformları arasında yer almaktadır. Kadın odaklı sosyal reformlar devlet feminizminin kadınların sosyal yaşamına yansımasıyla ele alınırken, eğitim gören kadının, kamusal alanda evlenip aile kurması ve birtakım kamusal hizmetlerde bulunması ön planda tutulmaktadır.

Romana bakıldığında, kadının kamusal alanda eğitim sayesinde bile olsa görünür olması, ağırlıklı olarak toplumsal koşullara bağlı yaşamları için bazen beklenmedik sonuçları beraberinde getirebilmektedir. Romanın kadın kahramanlarından Macide'nin yaşamı, bu anlamda verilebilecek bir örnektir. Romanda kız çocuklarının geleceklerini planlamalarında, ailelerinin büyük oranda belirleyiciliği söz konusudur. Romanda geçen ifadesiyle, orta mektebin bitirilmesi evlilik için yeterlidir. Öte yandan toplum içinde eğitimli olsun ya da olmasın, kızlar on beş on altı yaşlarında evlendirilirler. Macide'nin ablası da on beşinde evlenmiştir. Romanın yazıldığı 1930-1940'lı yılların toplumsal yapısı incelendiğinde günümüzde erken yaş evliliği olarak kabul edilen evliliklerin, o dönem açısından bir sosyal sorun kabul edilmediği ortadadır. Cumhuriyet tarihi boyunca toplumsal değişme ve gelişme süreçlerinde kadınlarla ilgili sosyal düzenlemelerde insan hak ve özgürlüklerine verilen değerin artmasıyla kadın olgusuna yaklaşımda farklılıklar olagelmiştir. Kadının toplumsal konumunun mahrem ve kamusal alanda tartışılması ile kadının insan haklarının gelişimi kadın lehine birtakım 
What Macide, who was not beaten by "İçimizdeki Şeytan" (The Devil inside Us) make us think in terms of gender / A. Şeker (pp. 297-308)

olumlu iyileşmeleri ortaya çıkarmıştır. Buna bağlı olarak kız çocuklarına karşı tutum ve çocukluk çağı algısı değişmiştir. Tarihsel açıdan 1930-1940'lı yıllarda kız çocuklarının eğitim olanaklarından yararlanması, medeniyet değişimi tasarımıyla kadınlara toplumsal görünürlük kazandırmaya çalışan Kemalist reformların devlet tecrübesiyle yakından ilişkilidir (Göle, 2016, s. 100). Durakbaşa'nın aktarımı ile:

Türkiye'de, Kemalist Cumhuriyet ideolojisi, modernist reformlarına bir cinsiyetsizleştirme (degendering) ve yeniden cinsiyetlileştirme (regendering) projesini de katmıştı. Kemalistlerin getirdiği yeni erkeklik ve kadınlık tarzlarıyla, geleneksel cinsiyet nosyonlarından bazıları "geri" sayılarak kötüleniyor, bazıları ise yeni bir bağlamda değerli kılınıyor, yüceltiliyordu. En önemlisi, yeni kadınlar, medeni bir millet olarak yeni Türk milletinin simgeleri hâline geldiler (Durakbaşa, 2014, s. 24).

$\mathrm{Bu}$ çerçevede yapılan sosyal reformların kadın yaşamlarındaki izleri roman yazarlarının da ilgisini çeker. Roman analizlerinde daha çok eleştirmenlerin kadın temsillerine ilişkin saptamaları yorum farklllıklarıyla gündem oluşturmuştur. Türk romanında kadın imgesini çözümleyen Kandiyoti, eleştirel bir yerden bakar. Tanzimat ve Cumhuriyet dönemi kent romanlarında kadınların âdetlerinin ve davranışlarının onların yozlaşmalarının örnekleri olarak kullanıldığı konusunda nettir. Kandiyoti’nin yorumlarında, kadın cinselliğinin tehlike ve kargaşanın yansıtıldığı önemli bir simgesel savaş alanı biçiminde işlenmesinin cinsiyetsiz tarif edilen kadın kahramanlarda somutlaştığına dair tezlere rastlamaktayı. Kandiyoti edebiyattaki bu tepkisel tavrın nedeninin kadınların özgürleşmesini ve peçeden çıkmalarını gerçekleştiren Kemalist reformların, bunu telafi edecek yeni bir simgesel peçeyi cinselliği bastırma peçesini- gerektirmesinden kaynaklandığını (Kandiyoti, 2015, s. 161) öne sürer. Bu minvalde Kemalizm, her ne kadar modernist bir ideoloji de olsa, kadınlar için temel geleneksel bir cins kimliği sunan geleneksel ahlâk normlarını değiştirmemiştir (Durakbaşa, 2014, s. 27). Buna benzer bir değerlendirme yapan Berktay'a göre ise Cumhuriyet-in resmî ideolojisi kadınların kamusal alana çıkmalarından, meslek sahibi olarak ev dışında çalışmalarından yanaydı. Çelişik gibi görünmekle beraber dönemin kadın konusundaki algısına yakından bakıldığında, gelenekselci kalıp ile modernleşmeci kalıp arasında, toplumsal cinsiyet rolleri yönünden temel bir farklılık olmadı̆̆ görülür (Berktay, 2015, s. 108). Şüphesiz ki bütün bunların edebi metinlerde bir karşllığı olmuştur. Bireytoplum diyalektiğini insanın bütünselliğinin farkına vararak yazan Sabahattin Ali'nin romanlarında kadın temsilinin, tarihsel ve toplumsal koşulları vermek yönüyle daha gerçekçi bir temelde kurgulanmış olduğunu belirtmek gerekir (Akatlı, 2012, s. 32). Sonuçta kurgu da hayattan beslenir. Hayat kurgunun imkânıdır; hatta onun sınırlarını tayin edebilir (Alver, 2012, s. 16). Sabahattin Ali'nin yapılandırdığı roman kahramanları hayatın aktığı bu kurguda geniş bir yelpazeye dağılır. Yazarın roman kahramanları aracılığıyla bir toplum eleştirisi sürdürdüğü açıktır. Bu sebeple onun romanlarında bütün kahramanlar "olumlu" kahraman değildir; fakat çağlarını, toplumsal ilişkileri ve zihniyetleriyle gözler önüne seren başarılı kahramanlardır (Timur, 2002, s. 94-395).

İnsanlık tarihi göstermektedir ki kadınların kamusal alana çıkışları ve görünürlük kazanmaları, medeniyet dönüşümünü sergilemesine karşın toplumsal değişim, kadınların yaşam alanlarına kolayca sirayet etmemektedir. Kadınların odakta olduğu tartışmalar içinde kadınların lehine bir dönüşüm, özellikle feminist hareketlerin talepleri arasında yer almıştır. Ne var ki eril hegemonya, kadınların kamusal alana eşit katılımının ve erkeklerle eşit haklara sahip olmasının nasıl oluştuğu konusunda baskın olmasının yanı sıra toplumsal cinsiyet ve toplumsal cinsiyet rollerinin toplumsal olarak inşa edildiği katı bir süreç oluşturur (Bahrani, 2018, s. 39). Bu saptama geleneksel ataerkil değerlere sahip, tarım geliriyle geçimini sağlayan ailelerin yaşadığı, Sabahattin Ali’nin romanının başladığı Balıkesir'deki insan ilişkileriyle örtüşmektedir. İnsan ilişkilerine yön veren cinsiyetçi sosyal gerçeklik, romandaki olayların İstanbul'a taşınmasıyla değişmemiştir. Örneğin romanda kadınlarla ilgili 
rahatlıkla dedikodu yapılabilmektedir. Kadınlardan erkeklerin arzularına göre hareket etmesi beklenir. Yalnızca erkekler değil, kadınlar da kendi hemcinslerini namus söz konusu olduğunda acımasızca eleştirebilmektedirler. Macide'ye kasabadaki öğretmeni Bedri’nin müzik yeteneği sebebiyle yakın ilgi duyması dedikodulara yol açmıştır. Bunun yanında Macide'nin müzik eğitimini ilerletmek için İstanbul'da akrabalarında kaldığında, aynı kasabadan, Darülfunun'da felsefe bölümünde öğrenim gören Ömer ile birlikteliğe doğru gidecek bir ilişkiyi yaşaması da eleştiri konusu yapılabilmektedir. Burada eleştiri oklarının hedefindeki kişi Ömer değildir. Sorun oluşturan konu, kadının değişmeye başlayan yaşam tarzını onaylamama ve bireyselliğine değer vermemeyle ilişkilidir. Macide'nin evinde kaldığı Emine Hanım, Macide’nin değişen yaşamına dair olumlu bir bakış açısına sahip değildir. Macide'nin Balıkesir'deki ailesinin, kızlarının geçimi için bu aileye maddi katkıda bulunmaması da Emine Hanım'ı tetiklemiştir. Kısaca Emine Hanım’ın cinsiyetçi tutumu Macide’ye karşı davranışlarını daha bir sertleştirmiştir.

Romanda, Ömer'in yakın çevresini oluşturan İstanbul'daki bir grup aydının, kadınları gazino ortamlarında eğlenilen ve cinsellik çağrıştıran varlıklar gibi algıladığını görmekteyiz. İçimizdeki Şeytan bu cinsiyetçi ortamları işleyiş niteliğiyle de tartışmaya açıktır. Macide ilkin ortamlara, nikâhsız yaşadığı eşi Ömer’in isteğiyle girer. Yakından tanıma olanağı kazandığı aydın geçinenler arasındaki ilişkileri samimi ve dürüst bulmaz. Macide, Ömer’in zayıflıklarına, içindeki şeytana yenik düşmesine, aldatmalarına, kendisine saygısı konusundaki eksikliklerine karşın kadınca bir gururla son ana kadar onu sahiplenir. Kadınlık gururunun kırıldığına inandığında ise Ömer’i terk etmeyi tasarlamıştır. Bu sırada Ömer, içinde yer aldığı aydın grubundan kaynaklı olarak kısa bir süreliğine karakola götürülür. Ömer, karakola kendisini görmeye gelen Macide ile görüşmediği gibi onu, Balıkesir'de öğretmenliği bırakıp annesi ve ablası için İstanbul'a yerleşen yakın arkadaşları Bedri'ye bir mal verir gibi emanet etmeye çalışır. Macide, muhtaç duruma düşmemek için Bedri ile yoluna devam edecektir. Bu arada Macide'nin müzik eğitimi için geldiği İstanbul'da sanata ilişkin bir varlık gösterememesini belki de yaşam zorluklarının daha ön plana geçmiş olmasıyla açıklamak gerekir.

Macide romanda anlatılan yazarların, şairlerin ve edebiyatçların "küçük" ve "riyakâr" dünyalarında kaybolup gitmez. Ancak kadın kimliğiyle toplum içinde var olmak, türlü zorlukları beraberinde getirmektedir. Öyle ki, kadının toplumsal alanda erkekten sonra gelmesinin alışılmışlığı yanında mahrem alanda erkeğin mizojiniyi andıran davranışlarına maruz kalması sık yaşanan bir olumsuzluk hâlidir. Kadının toplumsallaşma sürecinde kabul ettiği cinsiyetçi değerlerle, yaşamının ileriki yıllarında baş etme girişimi yeni kaygılara neden olurken psikososyal hayatı da derinden etkilenmektedir. Kadının yalnızca kamusal ve annelik rolleriyle güçlü görünmesi gerektiğine dair bir yargının toplum tarafından üretilmesi bu yüzleşmenin gecikmesinin nedenidir. Macide, ataerkil toplumda katlanmak zorunda olduğu dayatmalar karşısında var olmaya çalışırken cinsiyetçi praxis açısından bazı mesajlar taşır. Bu bağlamda İçimizdeki Şeytan, insanın içinde bulunduğu çelişkileri, insan olaylarını ve hayattaki çatışmaları göstermesi özelliğiyle insanın varlık yapısını tanıtır. Macide'nin sosyal kimliğiyle, cinsiyetçi bir toplumda karşı karşıya kaldığı sorunlar, romanın aynasına yansırken insan özgürleşmesi konusunda yeni analizler yapılmasına olanak sağlar. Bu noktada Sabahattin Ali, toplumsal gerçeklik içindeki toplumsal çelişkileri irdeleyip, iyi bir toplumun hangi değerler üzerine kurulması gerektiği doğrultusunda öngörü oluşturmaya katkı vererek toplumcu sanatçı rolüne uygun bir davranış sergiler.

Sabahattin Ali’nin kadın olgusuna bakış açısı, toplumsal yapıdan kaynaklı sorunlar, eşitsizlik, adaletsizlik ve yozlaşma dinamiğiyle sosyal gerçeklik temelinde önem kazanır. Sabahattin Ali, bu sorunlarla ilgili olarak kaba bir üslup ve ideolojik bir çerçeveden ziyade, estetik bir düzlemden hareket 
What Macide, who was not beaten by “İçimizdeki Şeytan” (The Devil inside Us) make us think in terms of gender / A. Şeker (pp. 297-308)

etmektedir. Onun romanında, çok genç yaşta kızların evlilik için yetiştirilmesi problemlerden yalnızca biridir. Romanlarına konu olan sosyal yapıda kadınlar, eğitim ve istihdam olanakları son derece sınırlı olduğundan kendilerini sadece evlilik yoluyla bulma olasılığıyla karşı karşıyadırlar. Diğer yandan kadınlar bu sosyal yapının en altında yer alırken kamusal alanda adil bir şekilde çalışamamakta, şiddetin her türlüsüne ve tecavüze maruz kalabilmektedirler. Tüm bireysel kompleksleri anlamaya değer gören Sabahattin Ali, kadının nesne olarak görülmesine karşıdır. Kadınlar için önemli olan toplumda eşit haklara sahip duyarlı ve özgür insanlar olmalarıdır. Kadınlar kendine güvenen ve özgür bireyler olarak sosyal, ekonomik ve politik yapıyla paralel giden çă̆daş değerlere adapte olabilirlerse bu durum kadınların lehine bir gelişme yaratabilir (Genç, 2018, s. 42-48).

İnsan ve toplum hangi koşulda olursa olsun anlaşılmaz olgular değildir. Bu sebeple sanatla hayat, sanatla insan arasında sıkı bir bağın bulunduğu söz götürmeyen bir hakikattir. Hayat ve insan, sanatın aynasında görünür, sanat onları yansıtır. Onun içindir ki, sanat, hayatın, insanın, çağın aynasıdır denir (Mengüşoğlu, 2017a, s. 130, 2017b, s. 278). Sabahattin Ali'nin roman anlayışı bu değerlendirmeyi hak etmektedir. Çünkü Sabahattin Ali’nin romanlarında Türkiye toplumsal yapısının gerçeklerini vurgulamaya dönük tespitleri sıkça göze çarpar. Yazar romanlarında sosyolojik bir derinlik sunar. Özellikle gelişmemiş kırsal bölgelerde yoğun ve trajik yaşanan eşitsizlikleri, şiddet yanlısı bürokratların, tüccarların, tefecilerin ve büyük toprak sahiplerinin neden olduğu sorunları aktarır. Onurlu bir toplum kurulması yolunda patriyarka kökenli eşitlikçi olmayan sosyal-ekonomik ögeleri ifşa eder. Roman mekânının İstanbul'a taşınmasıyla da insanlar için güvensizlik yaratan eşitsizlik kaynaklarını işlemeyi sürdürür. O da bilir ki, "ekonomik, politik ve sosyal düzen güvene dayalıdır ve yokluğunda bunların her biri çöker” (Bauman, 2014, s. 50). Aynı şekilde kadının toplumsal ve siyasal özgürleşimi ile ekonomik özerkliği, sağlıklı bir toplumsal bütünleşmenin sağlanması ve demokratik toplum düzeni kurmak için yerine getirilmesi gereken zorunlu koşullardır. Sabahattin Ali buradan ilerleyerek bir toplum araştırmacısı gibi insan-insan ve insan-toplum ilişkilerini romanın terazisine taşımayı başarmıştır.

\section{İçimizdeki Şeytan'ın Macide'sini toplumsal cinsiyet açısından değerlendirmek}

Edebî metinlerin değerlendirilmesinde her şeyden önemlisi anlamın endemik akıcılığını dikkate almaktır. Yazarın niyeti ile metne ilk ve son kez tutturulmaktan uzak olarak anlam okurun dünyasıyla birlikte değişmeye devam eder. Yazarın ürettiği metin kendi yaşamını kazanır. Metin anlamını, yazıldığı dönem ve mekândan türetir. Bu zaman ve mekânda, yazarın niyetleri diğer pek çoğunun arasında yalnızca bir unsurdur. Diğer yandan okur, metnin anlamını belirlemede yazardan daha özgür değildir. Onun yazardan bir gömlek üstün olduğu doğrudur. Çünkü metnin doğduğu zaman ve mekân hakkında daha fazla bilgiye sahip olabilir. Yazarın farkında olabildiği ve olmadığı tüm şeyleri bilir veya en azından bilebilir. Ancak okur da kendi yaşının bir çocuğudur. Bilgisi izin verdiği ölçüde anlar. Dolayısıyla zamanla edebi metin analizlerinde sosyolojik bağlamı göz önüne alarak yapılacak değerlendirmelerde çeşitlilikler gözlenebilmektedir (Bauman, 2017, s. 306). Bu süreçte toplumsal cinsiyete ve feminist eleştiriye dair yaklaşımların yükselişiyle ise edebî metin analizlerinde nesnel anlamaya dönük gelişmeler kaydedilmiştir. Feminist eleştiri de yeniden okuduğu her metne tarihi ve toplumsal bir boyut, disiplinlerarası bir kapsam ve en önemlisi yeni yorumlar kazandırmıştır (Parla, 2014, s. 20). Geriye dönüp bakıldığında toplumsal cinsiyetin ve kadın temsillerinin kritik edildiği edebî metinlerin çoğalmasıyla Sabahattin Ali'nin İçimizdeki Şeytan romanının da yazıldı̆̆ı zaman ve koşullar dikkate alınarak yeni anlam arayışlarına konu olduğu görülmektedir. 
Romanın başlangıcında, İstanbul'da insanları bir kıyıdan ötekine taşıyan bir vapurda, felsefe öğrencisi Ömer tarafından Nihat'a, dünya ve insan üzerine çekilen nutukta, kadınlarla ilgili söyledikleri, "erkek merkezli cinsiyet rejimini" (Sancar, 2014, s. 127) betimlemesinin yanında insancl bir öz içermemektedir: "Her şey beni sıkıyor. Mektep, profesörler, dersler, arkadaşlar... Hele kızlar... Hepsi beni sıkıyor... Hem de kusturacak kadar...” (Ali, 2006, s. 14). Bunları söyleyen Ömer, aynı saatte vapurda Balıkesir'den akrabası Emine Hanım'ın yanındaki Macide’yi görünce etkilenir. Güzel ve çekici bir kadın Ömer’in düşüncelerini değiştirmesi için yeterli olur. Bunlar Ömer’in karakter özelliklerini görmek adına önemli verilerdir. Vapurdaki tanışmalarından sonra, aynı gece alkol alıp, akrabalarının evine giderek, onların yanında kalan Macide ile bir ilişki başlatmayı deneyecektir. Ömer istediğini zamanla alır. Görünen o ki, Macide yaşadıkları ilişkide toplumsal cinsiyet rollerine uygun davranmasıyla bir erkeğin etkisinde olmayı çoktan kabul etmiştir: “...yalnız olduğu zamanki bütün mücadelesi ani olarak durmuş, iç ve dış hayatına ait her şey, yanında sessizce yürümeye başlayan delikanlının hükmü altına girmişti. Analarının kanatları altına saklanan civcivlerin duyduğu emniyet ve gönül rahatına çok benzeyen bu kendini teslim etme hissi, Macide'nin hiç de gururunu hirpalamıordu...” (Ali, 2006, s. 89).

Macide'yle yaşadıkları süre içinde Ömer tutarsız kişiliğiyle okurun gözlem alanına sunulur. Postanede bir akrabasının kayırmasıyla çalışmaya başlar. Elde ettiği gelir, Macide ile geçinmesine yetmemektedir. Etraftan borç alırlar. Arkadaşları Bedri'nin gelirini, Ömer ve Macide'yle bölüşmesi ise kimi sorunları beraberinde getirir. Öte yandan Ömer'in aydın geçinen çevresinin içinde bazı tiplerin alkol aldıklarında Macide'ye yönelmeleri Macide'yi sürekli tetikte tutar. Macide bu davranışları onur kırıcı ve aşağılayıcı bir şekilde duyumsar.

Yazar, oluşturduğu roman kahramanları arasında Macide'yi boylamsal ele alır. Geçmişine, okul yıllarına, İstanbul'a gelişine, orada yaşayış biçimine kadar bir bütün hâlinde işler. Bu anlamda yazar, Yalçın'ı şu teorik saptamasını adeta doğrular, "romana asıl niteliğini kazandıran, roman kahramanının tutum ve davranışlarının oluşmasına ortam sağlayan çevreyi roman kurgusuna aktarabilmeyi" başarmaktır (Yalçın, 2011, s. 51). Fakat roman karakterlerinin canlı bir varlığın taklidi olmadığı, kurmaca bir varlık olduğu kabul edildiği anımsanacak olursa (Kundera, 2014, s. 41), Macide'nin de sosyal çevresi içinde işlenirken roman kahramanı niteliğiyle kurmaca bir yanının olduğu unutulmamalıdır.

Macide'nin evlerinde kaldığı Emine Hanım yıllar önce Balıkesir'den İstanbul'a yerleşmiştir. Balıkesir'e gittiğginde akrabalarının kızı Macide'yle tanışır. Romanda kronolojik açıdan geriye gidildiğinde Macide şu şekilde değerlendirilebilir. Balıkesir'in bir kasabasında, orta mektebe giden Macide'de eğitim, değişime neden olmuştur. Şöyle ki "mektepteki hayat, okuduğu kitapların ve dinlediği derslerin anlattı̆̆ şeyler onun, elli sene evvel taş kesilip olduğu yerde kalmış gibi hakikatten uzak olan evinden ve oradaki yaşayışından tamamen ayrı"dır (Ali, 2006, s. 28). Macide'nin kasabadaki öğrencilik yılları, kendi isteğiyle arkadaşlarından uzak durarak geçer. Romanın ilerleyen sayfalarında, İstanbul'da konservatuvardaki arkadaşları arasındayken bu sosyal soğukluğu sürer. Bu durum romanda şöyle ifade edilir: "Macide orta mektepteyken de arkadaşlarını pek beğenmezdi. Konservatuvarda tesadüf ettiği ve pek az konuştuğu kızlar hakkında ise henüz fikri yoktu. Yalnız muhakkak olan bir şey, buradakilerin, şimdiye kadar gördüklerine asla benzemedikleri ve daha acayip olduklarıydı” (Ali, 2006, s. 140). Macide'nin hemcinsleriyle arkadaşlık ilişkisi geliştirip geliştiremediği sorunsalı fikir yürütmeye açı bir konudur. Bunun yanıtına, ne Balıkesir'de kasabada karma eğitim veren okulda okurken ne de İstanbul'da konservatuvarda eğitim sürecindeki yaşantısında rastlanır. Bazen aşırıya gidip, orta mektepteki arkadaşlarını dedikoducu, amaçsız bir hiç olarak görürken konservatuvardakilerini ise 
What Macide, who was not beaten by “İçimizdeki Şeytan” (The Devil inside Us) make us think in terms of gender / A. Şeker (pp. 297-308)

hiçten daha ileri görür, ancak ona göre "saçma insanlar olmalarıyla birlikte ne olursa olsun bir sanata kendilerini adamışlardır” (Ali, 2006, s. 141). Genelde eğitim gördüğü kız arkadaşları hakkında olumlu düşüncelere sahip değildir. Düşünceleri İstanbul'da öyle bir hâl alır ki şu itirafı yapar: "Ömer olmasa bir dakika durulmaz...” (Ali, 2006, s. 141). Macide'nin kendi açmazları içinde kısır döngüye hapsolmuş Ömer'e her şeyini bağlaması, toplumsal cinsiyetin kurulumu bakımından eleştirilmesi gereken tabloyu ortaya çıkarır. Bir genç kızı bu aşamaya getiren sosyalleşme sürecinde karşı karşıya kaldığı çatışmalar olabileceği gibi kişiliğinden kaynaklı özellikleri de hesaba katmak gerekir.

Macide'ye ilişkin değerlendirmemize dönecek olursak, önce öğretmen Necati Bey sonra Bedri öğretmenin yönlendirmesiyle müzikle ilgilenmiştir. Macide için her şey aslında tesadüflerden ibarettir. Orta mektebi bitirdiğinde bu tezi açıç̧a ortaya çıkar:

\begin{abstract}
Bundan sonra ne yapılacağını ne anası, ne babası, ne hocaları, ne de herhangi bir kızın anası, babası ve hocası biliyordu. Herkes gibi onun da akıbetini tesadüfler tayin edecekti. Belki bir müddet sonra bir kocaya vermek isteyecekler, o reddedecek, başka birini ortaya sürecekler, onu da istemeyecek, bu mücadele pek de uzun sürmeden genç kızın sebepsiz ısrarı sona erecek, o da nihayet, 'ne olursa olsun' deyip boyun eğecek ve bir şeyler, bir şeyler olacaktı. Demek hayat böyle iki adım ilerisi bile görülmeyen sisli ve yalpalı bir denizdi. Tesadüflerin oyuncağı olacak olduktan sonra ne diye bir irademiz vardı? Kullanamadıktan sonra göğsümüzü dolduran hisler ve kafamızda kımıldayan düşünceler neye yarardı? Yaşayışımıza ve etrafımıza şekil vermek arzusuyla dünyaya gelmekten ise hayatın ve muhitin verdiği şekli kolayca alacak kadar boş ve yumuşak olmak daha rahat, daha makul değil miydi? (Ali, 2006, s. 42-43).
\end{abstract}

Toplumsal koşulların insanlar üzerindeki gücünü yukarıdaki cümleler özetlemektedir. Macide aracılı̆̆ıyla verilen sosyal bilgi, kadınların konumunu görmek anlamında toplumsal yapıya ilişkin cinsiyetçi izleri dişa vurur. Orta mektep bitirildikten sonra toplumun, kız çocuğundan beklediğini yansıtması noktasında önemlidir. Onun hayatının amacı olan müzik, yaşadığı koşullarda, kızların kocalarının toplumdaki seviyelerini yüksek tutmak yolunda heveslenilen bir uğraşı olarak görülüyordu (Ali, 2006, s. 43). Tesadüfler Macide'nin hayatının seyrini biçimler. Örneğin yaşadıkları kasabayı ziyaretlerinde Emine Hanım, ağırbaşlı ve güzel akraba kızının müziğe merakını öğrenince, İstanbul'da konservatuvara kaydolmasına yardımcı olur. Bu esnada Emine Hanım’ın aileyi ikna etmek için ileri sürdüğü şey ilginçtir: "Kızınıza burada memurdan başka koca bulamazsınız ki... Halbuki o doktorlara, mühendislere layı... Hele birkaç sene bizde kalsın da görürsünüz” diye ilave eder (Ali, 2006, s. 44).

Macide'nin yerleştĭgi İstanbul'da, konservatuvar yılları boyunca bir müzik aleti çaldığına rastlanmaz. Büyük olasılıkla bunun nedeni henüz kendine güvenmiyor olmasıyla ya da yazarın işlemediği başka şeylerden kaynaklanıyor olabilir. Macide, Emine Hanım ve Yağ iskelesindeki mağazasında yağcılık yapan eşi Galip ile çocukları Nuri ve Semiha'yla yaşamaktadır. Önceleri kendi âleminde, eğlencelerde günü geçiren Emine Hanım, ekonomik şartlarının bozulmasıyla Macide'ye dikkat etmeye başlar. Toplumsal koşullar itibarıyla bu eşraf ailesi, İstanbul'a gittiklerinde içinde bulundukları ticari ilişkileri geliştiremeyince, ekonomik ve sosyal statülerinde kayıp yaşarlar. Yanlarına aldıkları Macide artık göze batmaktadır. Macide'yi huzursuzluğa sürüklemenin en kolay yolunu deneyeceklerdir. Ekonomik destekte bulunmayan Macide’yi namusu üzerinden eleştirerek, bir gece evden ayrılmasına ve Ömer’in hayatına dâhil olmasına yol açarlar. Macide evden ayrılacă̆ı gün Emine Hanım dedikodu yapar:

Komşular gelip gelip seni anlatmaya başladılar; kimisi Beyoğlu'nda bir delikanlı ile gördüğünü, kimisi yaşlı bir beyle saza gittiğini söylüyor. Ne yalan söyleyeyim, evvela inanasım gelmedi. Soyun sopun malum. Ailemizden elhamdülillah şimdiye kadar dile gelmiş kimse yoktur. Velakin bütün Müslümanlar yalancı değil ya... Yemin kasem ederek anlattılar... Bir değil, beş değil... Sen aklını başına toplayasın diye bekledik... Ama daha fazlasına müsaademiz yok (Ali, 2006, s. 103). 
Genç kadının yaşamına dönük bu tür yargılamaları devam eder. Kızı Semiha bile daldığı romandan başını kaldırıp, annesinin aşağılayıcı davranışlarından ne kadar mutlu olduğunu saklamaz. Ailenin tutumunun temelinde bozulan ekonomileri ile Macide'nin annesine yazdıkları mektubun karşllı̆ında istedikleri ekonomik desteği alamamış olmaları yer alır. Ekonomik sorunları devam edince, dışlayıcı halleri daha da acımasızlaşır. Evde hizmetçilik yapan Fatma da sonunda başka bir iş aramaya başlar. Macide'nin annesinin ölen eşinin hesaplarının tasfiye edileceğinden, yardım yapamayacağını yazdığı mektuptan sonra, Emine Hanım her ne kadar dedikodular ve ahlaki bir arayışla Macide'yi köşe sıkıştırmaya kalksa bile eşi Galip Bey, sorunun ekonomik olduğunu, karısının incitici tavırlarına rağmen dile getirir. Bunun üzerine, "Macide gözlerini teyzesine dikmişti. İptidai zekâsıyla karşısındakini kandırmaya, asıl maksadını saklamaya çalışan ve bunda pek az muvaffak olan ihtiyar kadın, Macide’ye bu âna kadar hiç böyle iğrenç görünmemişti. Düşündüklerini saklamayarak dışarı vuruveren zavallı Galip amca, karısına nazaran çok daha dürüsttü...” (Ali, 2006, s. 105). İleri giden Emine Hanım: “...Doğrusunu istersen, ben annene yazacağım ve kızının yaptıklarından haberin olsun, gönlün razı ise burada bırak, değilse çaresine bak" diyerek tehdit dili kullanır (Ali, 2006, s. 105). Yaşlı bir kadının öncesinde isteyerek yanına aldığı akraba kızını, ailesi zordayken düşürdüğü psikolojik huzursuzluk hâli, yaşlı kadın roman karakterleriyle özdeş kılınan tutumları görmek bakımından edebiyatta uzun bir geçmişi anımsatır. Roman kahramanları arasında yaşlı kadınların genel özelliklerinden bazıları bu karakterde verilir. Yani kendi rahatını düşünen, rahatı bozulduğunda yapamayacağı kötülüğü olmayan, hatta baş edebileceğine inandığı bir başka genç kadın karakteri kolaylıkla bir çirkin sona itebilen davranışlar, Türk romanlarında da ele alınan temalar içinde yer alır. Burada söz konusu edilen, kadın aleyhine işleyen namusla ilgili ötekileştirici mekanizmayı adeta yeniden üreten ataerkil kültürel bakış açısıdır. Kendi maddi koşulları, babasının ölümü, annesinin, ablasının ve hiç sevmediği eniştesinin yanına taşınması ile sosyal destek olanaklarından ayrı düşüşü, Macide'nin özgür davranmasının önünde engel oluşturmuştur. Ömer'le birlikteliği bir yana kızın eve geç gelişleri ve çıkan dedikodular, onun bir gece evden ayrılmasını beraberinde getirir. Ömer’in kiraladığı bir odalık pansiyonuna yaşı küçük olduğundan, nikâhsız eşi olarak yerleşir. Ömer çok kolay bir şekilde, Macide'nin muhtaç konuma düşmesinden yararlanmasını bilmiştir. Her ne kadar güzelliğinden etkilenip âşı olduğunu ifade etse dahi bu ilişkinin sorumluluğunu taşıamaz. Sorumsuzluğunu ise içindeki şeytana yükler. Örneğin Ömer'in kendisiyle hesaplaştığı bir anda, düzelebileceğine dair düşünceleri sonraki sayfalarda tersine döner: "Her şeyi düzeltebilirim, onu da, kendimi de kurtarabilirim. Neden olmasın? Ben hayata bağlanmak için ona muhtacım, o idare edilmek için bana muhtaç... Ben onu görmeden evvel hayatın manasını bilmiyordum, bulamamıştım. Şimdi görüyorum ki, o da bensiz yaşayamayacak...” (Ali, 2006, s. 114).

Ömer farkındadır ki, erkeğin egemen olduğu ataerkil geleneksel toplumlarda sıkça rastlandığı gibi kadın, idare edilmek için erkeğin iradesine bırakılır. Yaşadığ görevi erkeğe vermiştir. Ancak Ömer bunun üstesinden gelemeyeceğini anlar. Öyle ki Macide’nin kendisinden ayrılmak isteğini ona yaşatmayacak, kendi başlattığı ilişkiyi, bencilliği uğruna yine kendisi bitirecektir. Bir çıkar yol ararken riyakârca davranarak, kadına daha fazla acı çektirmek istemediğini ifade eder. Romanın içeriğinden bunun Ömer’in kendi kişiliğinden kaynaklandığını çıkarmak olasıdır. Toplum, iç karmaşasını bir kenara bırakıp ataerkil değerlerle toplumsallaştırdığı erkeğe, ilişki başlatma ve bitirme yeterliliğini, gücünü ve şansını vermekten imtina etmeyecektir. Çünkü bu tarz eşitsiz ilişki biçimi, erkek egemen toplumların bir özelliğidir. Ömer somut koşulları çok iyi tahlil ettiği halde, kendi yaşamında başarısızdır. Çoğu zaman dürüst değildir. Bilgili olmasını bir yerde dürüst olmama yönünü pekiştirmek için kullanır ve sorumluluklarını yerine getiremeyişini ise içimizdeki şeytanı günah keçisi yaparak kendi dışına atmayı başarır. Romanın sonuna kadar içindeki şeytan sayesinde kendisi olamaz. Macide’yle ilişkisini saygın bir şekilde yürütememiştir. Örneğin Macide’nin 
What Macide, who was not beaten by "İçimizdeki Şeytan" (The Devil inside Us) make us think in terms of gender / A. Şeker (pp. 297-308)

yaşına bağlı olduğu için nikâhsız süren birliktelikle, aynı çatı altında bir aile kurarlar. Yaşamın maddi ve sosyal zorlukları karşısında bunalan, bu yetmiyormuş gibi kendi kişilik karmaşasına yenik düşen Ömer, ailesinin idaresi için toplumun ona verdiği erkeklik rolünü yerine getiremediğinde, kendisine sığınacak gerekçeler bulur. Bunaldığında, Macide’ye, "Bana kızma!.. Benim kusuruma bakma! Bana kocan gibi değil, çocuğun gibi bak!” diye yalvararak (Ali, 2006, s. 170) mahrem alanda kadını kullanacak kadar ileri gitmesini bilir. Öyle bir hâl alır ki sızlanışları, "Ömer, insanı istemediği şeyleri yapmaya mecbur eden ve herkeste az çok bulunan bir şeytanın mevcut olduğuna Macide’yi de inandırır. Genç kadın şimdilik kendinde tezahürlerini görmediği bu acayip mahlûkun mahiyetini iyice kavrayamıyor, fakat bir gün meydana çıkıp onu da avcuna almasından korkuyordu" (Ali, 2006, s. 170171). Romanın erkek kahramanının her hâlükârda, kadını kendisine inandırmasında üstüne yoktur. Öte yandan Macide yaşamını birleştirdiği Ömer'de birtakım insani değerler olmadığını kanıksamaya başlamıştır. Bunu deneyimlemesi ona acı verir. Çünkü "Macide kendisini her an düşünen, sadece aşk ve istek değil, bunlar derecesinde de hürmet telkin eden, sadece bir küçük kardeş, yaramaz bir çocuk değil, aynı zamanda bir ağabey, bir destek olan insanın yakınlı̆ııı daima arıyordu” (Ali, 2006, s. 172). Kuşkusuz Ömer'in, iç hesaplaşmalarında kendine inanmayan, hatta içinde melun bir şeytanla tartışan aşağılık bir kişiliğe sahip olduğunu ifade ettiği anlar olmuştur. Kendisine dürüst olmayan bir insan, başkalarına ne kadar dürüst olabilirdi ki? Yazar, bu noktada Macide'nin var oluşunu irdeler. Aralarındaki ilişki kötü gittiğinde bile ne yazık ki, “en ümit etmediği zamanlarda onu Ömer’e bağlayan bir his, bu adamın şu anda yüzde yüz kendisine muhtaç olduğu hissi ve bunun verdiği gurur, genç kadına her şeyi unutturuyordu...” (Ali, 2006, s. 196). Toplum kadında nasıl bir duygu inşa etmeyi başarmış olmalı ki, en kötü yanlarıyla bile gelse erkeğinin açmazlarını kurtarma anlamında başarısız olmak istememektedir. Erkeğe göre kendine yön veren kadının, bu mücadeleden geri durması veya başarısızlığı belki de toplumun hanesine yazılacak ve kadına fatura edilecektir. İlişkinin sürmesi için Macide cömert davranan taraf olur. Bu niteliğiyle Macide, üyesi olduğu toplumda, kurulu toplumsal cinsiyetin kritiğini yapmamız için kadın roman karakteri olarak çok daha fazlasını yapar. Ayrıca aydınların dünyasında tanık olduğu davranış bozukluklarını, birbirinin arkasından atıp yüz yüze geldiklerinde riyakâr davranışlarını sorgular. Bedri’nin en zor zamanlarda yol göstericiliği, gerçekçiliği ve rasyonelliğinin etkisi de bu bilinçlenmeyi edinmesine katkı sağlamıştır.

Ömer romanın sonlarına doğru, İstanbul'da yaşayan bir grup aydının kurdukları tezgâha kurban giden gençler tutuklandığında bir süreliğine karakolda tutulur. Burada bir karar alır. Kendisini yenileyecektir. Bunun için Macide'den ayrılmayı planlar. Macide'yi Bedri'ye teslim eder. Kardeş ya da sevgili olarak artık nasıl kabul ederse, ona kalmıştır. Macide'yi özel mülkiyeti gibi sunar. Macide'nin karşısına geçip insani bir şekilde konuşmaz. Oysa bir ara Macide ondan ayrılmak için intiharı bile düşünmüştür. Ona ayrılacağını söyleyecektir. Buna firsat kalmadan Ömer’in, Macide’ye Bedri aracılı̆̆ıyla ayrılmak istediğini iletmesi, hâlen içinde büyüttüğü şeytanın bütün kişiliğini sarmış olmasından başka bir şey değildir. Açıççsı bir şeytana gerek yoktur. Ömer’in, içinde kaybolduğu karanlığını büyüten cinsiyetçi kişilik bozuklukları yeterlidir. Öztürk'e göre kadına karşı güven duymayan, onu güçsüz, aşağı gören, onu sürekli denetim altında tutmaya çalışan, kendi dürtüselliğinin sorumluluğunu kadına yükleyen erkeğin temel sorunu özgüven eksikliğidir. Bu anlamda Ömer, özerk bir birey olamamıştır. Geleneksel, kırsal, yarı-kırsal toplum kesimlerinden çağdaş, kentsel toplum kesimlerine doğru değişen ve azalan oranlarda, erkeğin kadından beklentileri daha çok isteklerinin karşılanması, hizmet edilmek, karşı gelinmemekle ilgili olmuştur. Bir başka deyişle erkek, üstünlügünün kabul edilmesini beklemeye koşullanmıştır (Öztürk, 2016, s. 87-101). Ömer’in Macide ile karşı karşıya gelmeden, Bedri aracılığıyla ilişkilerine yön vermeye çalışmasının psikososyal dinamiğini bu mantık üzerinden giderek çözümlemek gerçekçi olacaktır. Kısaca Ömer’in kişilik yapısı onu bir kimlik sahibi yapacak yeterlilikte değildir. Bireysel kimlik edinimini yerine getiremeyen Ömer, 
içinde büyüttüğü şeytanı, karşılaştığı her sorunla baş edemediğinde yardımcı bir aygıt olarak kullanmayı tercih eder. Saplantılı bir biçimde içindeki şeytanla ilişki kurması ve ilişkiyi beceriyle sürdürmesi neticede içgörü kazanamamasının bedelini, hayatına giren kadına ödetmesiyle sonuçlanır.

Yazar, romanda Macide'nin Bedri ile yoluna devam etmesini sağlar. Macide de buna hazırdır. Hatta Bedri'ye evde bakıma muhtaç ablası Mediha'ya çok iyi bakabileceğinin garantisini verir. Kuşkusuz feminist eleştiriye açık bu kararını, hayatta kalma mücadelesine ilişkin geliştirdiği bir strateji olarak kabul etmek gerekir. Böylece roman başka bir maceraya doğru yol alır. Burada, Macide'nin yaşadığı erkek egemen toplumda güç sahibi olmaması temel meseledir. Bu nedenle özgür davranamamaktadır. Çünkü güç sahibi olmak daha özgür olarak eyleyebilmek demektir; ancak güç sahibi olmamak ya da başkalarından daha az güç sahibi olmak, kişinin seçim özgürlüğünün başkalarınca alınmış kararlar tarafından sınırlanması anlamına gelir (Bauman, 2015, s. 128). Bu minval üzere erkek-kadın karşıtlı̆̆ı açısından bakılacak olursa, hep erkeğin üstünlüğünü belirten bir değerler hiyerarşisinin Macide somutunda tüm kadınların aleyhine bir ideolojiyi kurumsallaştırdığını söyleyebiliriz (Moran, 1999, s. 261). Başka bir ifadeyle ataerkil toplum düzenlenişinde, kadının belirsizlik içinde yaşamasını beklemek, kadın için tedirgin edicidir. Kadının bu belirsizlikte aidiyetsizlik haliyle yüzleşmemesi ya da yüzleşmek istememesi ataerkilliğin ürettiği yabancılaşmaya maruz kalmasına neden olur. Yabancılaşmasının faturasının kadına çıkarılması ise başlı başına mahrem ve kamusal alanda irade sahibi olmasının yolunu kapatan bir etkendir.

Genel hatlarıyla değerlendirildiğinde modern çağın başlangıcıyla anılan roman, bir kez yazıldı̆̆ı için öyle kalmaya mecburdur. Tarihsel gelişimi sürecinde sosyolojik özüyle roman olgusu ve roman içeriğiyle ilgili eleştirmenlerin kanısı, değişimin kuralları gereği yeni eleştirel yaklaşımlara ehliyet kazandırırken okur da bu pratikten yararlanmayı ihmal etmez. Değişen yaşam koşullarına eşlik eden trajediler, kaygılar, korkular ve çatışmalar var oldukça romanın işlevi sürer. Roman ögesini evrensel kılan, demokratik hoşgörü inancı ve farklılıklara duyulan saygıdır. Toplumun demokratikleşmesi romanın demokratikleşmesini de besler. Bu açıdan romanın her koşulda okunabilirliği, ona ölümsüzlük getirirken, ele alınışına simetrik farklılıklar eşlik eder. Halihazırda romanın toplumsal çelişkilere eğilmesi, bireysel çatışmalara yoğunlaşması ise sosyal belge olarak kabul edilmesini beraberinde getirir. Romanın eğildiği küresel eşitsizlikleri ilgilendiren konular, sosyal ve bireysel dramlar, toplumsal sorunlar öneminden bir şey kaybetmez. Çağdaş Türk roman geleneğinde Sabahattin Ali'nin romanları hem işlediği sosyal konular hem insan hayatında erkek ve kadın temsillerine ilişkin ufuk açıcı niteliğe sahip olması yönüyle sosyolojik analizler yapılmasını hak eder. Bu anlamda Sabahattin Ali Íçimizdeki Şeytan'da bazı aydınların içinde bulunduğu riyakârlıkları göstermeye çalışırken okuru Macide üzerinden aydınlanmış bir sona ulaştırır. Bu sonuçtan yola çıkarak okur, bir kişisel değerlendirme yapabilirse roman amacına ulaşmış olacaktır. Yoksa İçimizdeki Şeytan romanı söz konusu olduğunda gündeme gelen Peyami Safa, Atsız ya da diğerlerini roman karakterleri arasında Nihat, Darülfünun'da Profesör Hikmet, Emin Kâmil, İsmet Şerif, muharrir Hüseyin ve Ümit gibi kişiler içinden çıkarıp bir köşeye oturtup, onların nasıl ele alındığını kritik etmek, beraberinde politik bir tartışma getirir ki, bunu yapmak geri planda gizlenen cinsiyetçi praxisi doğru değerlendirebilmeye yönelik engel teşkil edebilir. Başka bir çalışmada, aydınlar sosyolojisi bağlamında, aydınların savundukları düşünceler, gruplaşmaları, siyaset kurumu aydın ilişkisi, aydın yabancılaşmasına kadar bir dizi konu sistematik olarak ele alınabilir. Kuşkusuz bu açıdan da "sayısız kere roman yazarları çağdaşlarının yüzleştiği ve üstesinden gelmekte zorlandığı konuları, yeni eğilimleri ilk fark edip inceleyen kişiler arasında yer alırlar” (Bauman ve Mazzeo, 2019, s. 12). Sonuçta okurun sanat yapitlarına bakış açısı değişmektedir. Her kuşak sanat yapıtını yaşadığı koşulların değerleriyle kritik eder. "Eski” ve "yeni” her kuşak, sanat yapıtlarını belli bir dünyanın suretinde hayal 
What Macide, who was not beaten by “İ̧̧imizdeki Şeytan” (The Devil inside Us) make us think in terms of gender / A. Şeker (pp. 297-308)

eder ki bu dünyanın hakiki doğası ve anlamının da bu yapıtlarca gözler önüne serileceği ve sorgulamaya açık hale getirileceği varsayılır ve umulur. Bu dünyanın, sanatçıların emekleri sayesinde daha anlaşılır, belki de tamamen anlaşılır kılınması beklenir (Bauman, 2013, s. 87). Denebilir ki, Íçimizdeki Şeytan romanındaki aydın tipler, topluma yabancılaşmış olmanın yanında dar görüşlüdürler. Yalnızca kendi memnuniyetlerinin ve arzularının peşinde koşmaları onların gerçeklere ulaşmalarının önünde büyük bir engel teşkil eder. Bu ayrıntılarıyla, roman boyunca entelektüel bir muhalefetin adresi olmayı başaramamış görünürler. Kısaca entelektüel ve aydın olmanın anlamı, kişinin kendi mesleği ya da sanat türü ile ilgili kısmi uğraşının üzerine çıkması ve içinde yaşadığı zamanın hakikat, yargı ve beğeni gibi küresel konularıyla ilgilenmesi demektir (Bauman, 1996, s. 8). Romandaki aydın tiplerin, kendilerine ait özellikleri değerlendirildiğinde, kesinlikle entelektüel ve aydın kategorisi içinde yer almadıkları ileri sürülebilir.

\section{Sonuç}

Türk romanında kurgulanan kadın imgesinin Türk tarihi içindeki sosyal, ekonomik ve siyasal değişimlerden nasıl etkilendiğini çeşitli yönleriyle değerlendirmek olanaklıdır. Bu anlamda yazarların kadınlar hakkındaki öznel tutumu göz ardı edilmese bile romanların yazıldığı toplumsal dönemdeki değişimlerin etkisindeki sosyal karakter biçiminde işlenen kadın kimliği farklı özellikleriyle romanlarda karşımıza çıkabilmektedir (Şeker, 2020, s. 3). Bu metinde İçimizdeki Şeytan romanına konu olan erkek egemen bir toplum yapısındaki cinsiyet kurulumuna eleştirel bir yaklaşım geliştirilirken romanın kadın kahramanı Macide'nin toplumdaki tanıklı̆̆ı, kadın olarak toplumda yaşadığı sorunlar irdelenmiştir. Roman, yaşadığı acılara, aşă̆ılanmalara ve düştüğü gurur kırıcı durumlara karşı bir kadın kahramanı odağına almakla birlikte, romanın yansıttığı tarihsel ve sosyal zamanda toplumsal cinsiyet inşasını görmek anlamında bilgi vericidir. Özetle Ömer’in hayatı bir insanı sevip ona bağlanma duygusuna karşıllk verememekle geçerken, içindeki şeytana yenilmesi trajik sonu olur. Bireyselleşme sorunu yaşayan Ömer aynı zamanda sosyal açıdan uyumsuz bir tiptir. Oysa Ömer’in yenildiği “şeytana” Macide yenilmez. Ne var ki Macide de erkek egemen bir toplumda yalnız kalmayı göze alamaz, toplumdan yardım da ummaz. Belirsizlik endişesine kapılmamak uğruna erkeğin kadına egemenlik kurduğu toplumda içinde bulunduğu durumu gözetip cinsiyet rollerine sadık kalarak Bedri ile yaşamına devam etmeye karar verir. Kadın için talihsizliklerle dolu erkek egemen bir toplumda işsizlik, gelirsizlik, yoksulluk, evsizlik, gelecek yokluğu, yetersiz toplumsal koruma sistemi, aile sosyal desteğinin olmayışı ve bunların üzerine nikahsız eşi Ömer’in güven vermeyen karakteri eklenince Macide'nin yaşam seyriyle ilgili roman yazarından gerçekçi olmayan bir beklentiye girmek haksızlık olur. Erkek egemen toplumlar hiç kuşkusuz kadın kimliğini tehdit eden süreçler üretir. Romanda bütün benliğiyle örülü bireysel varoluşuyla Macide, yaşadığı sosyal yapıdan kaynaklı cinsiyetçi sorunlarla yüzleşmek zorunda kalmıştır. Topluma ait değerleri, Macide'nin bireysel varoluşu bakımından irdelediğimizde patriyarka en güçlü öge olarak ortaya çıkar. Patriyarkanın gerçek bir olgu olması, toplumsal cinsiyet açısından Macide’nin penceresinden okur için elverişli tartışmaların çıkış noktasını oluşturur.

Sabahattin Ali’nin toplumcu gerçekçi bir düşünceyle ele aldığı İçimizdeki Şeytan romanı, edebiyat sosyolojisi yönüyle irdelendiğinde diyebiliriz ki, Türk modernleşmesinin ögelerini içinde barındırdığı dönemde toplumda kadın ve erkek kimliğinin oluşumunun dinamiğini yakından görmek isteyenler için yazıldı ̆̆ tarihlerde ve sonrasında değerinden bir şey kaybetmemiştir. Roman, toplumda gücü olmayanları, dışlananları, sosyal ekonomik eşitsizlikleri yaşayanları, ötekileştirilenleri vb. anlatabilirse ancak sosyolojik bir işlev edinir. İçimizdeki Şeytan'ın ötekisi toplumsal cinsiyet eşitsizliğine maruz bırakılan Macide'dir. Toplumun göstergesi ve sessiz tanığı Macide, toplumsal yapının kadına dayattığı 
sınırları aşamamıştır. Çünkü ataerkil toplum tüm hukuki düzenlemelere rağmen, tarih boyunca kadını kurbanlaştırmadaki arayışlarını kadının ötekileştirilmesinde somutlaştırmıştır. Feminist edebiyat sosyolojisi için kabul edilemez olan bu tutum, kadını insan haklarına sahip olma durumundan da uzaklaştırır. Böylece kadın aleyhindeki cinsiyet eşitsizliğini içeren kimlik inşa etme süreci toplumsal olarak kodlanır. Dolayısıyla romanın kadın kahramanı Macide'nin, ataerkil toplumsal hiyerarşinin kurumsallaştırdığı sorunlara maruz kalması neticesinde bireysel bir çıkış yapması ve başkaldırması dışlanmasına neden olabilecektir. Toplumsal meselelerle mücadelede bireysel çıkışlarla başarılı bir sonuca gidilmesini varsaymak basite kaçmak olur. Macide'den bu anlamda bir şey beklemek o günkü toplumsal yapı dikkate alındığında pek gerçekçi değildir. Toplumsal gerçekler üzerine romanını kuran yazardan roman kahramanı Macide'yi böyle bir davranışa itmesini ummak ise roman anlayışını yansıtıcı bir tutum olmaz. Bununla birlikte öz-saygısını korumaya çalışan Macide’yi kötüye karşı durabilen bir karakter olarak görmek gerekir.

Sonuç olarak İçimizdeki Şeytan romanının, kadının kamusal alan içinde görünürlüğünün işlenmesine ilişkin değerlendirmeler yapılmasına olanak sağlarken, feminist edebiyat eleştirisi, edebiyat sosyolojisi ve toplumsal cinsiyet çalışmaları bakımından da üzerinde durulması gereken özellikler içerdiğinin altını çizmek gerekir.

\section{Kaynakça}

Akatll, F. (2012). Eleştirinin sesi. İstanbul: Kırmızı Kedi.

Ali, S. (2006). İ̧imizdeki şeytan. İstanbul: Yapı Kredi.

Alver, K. (2012). Edebiyata giriş. K. Alver (Ed.). Edebiyat sosyolojisi incelemeleri içinde (ss.11-46). Ankara: Hece.

Bahrani, Z. (2018). Babil'in kadınları/Mezopotamya'da toplumsal cinsiyet ve temsil. S. Çalcı (Çev.). İstanbul: Kolektif.

Bauman, Z. (1996). Yasa koyucular ile yorumcular/modernite, postmodernite ve entelektüeller üzerine. K. Atakay (Çev.). İstanbul: Metis.

Bauman, Z. (2013). Yaşam sanatı. A. Sarı (Çev.). İstanbul: Versus.

Bauman, Z. (2014). Bu bir günlük değildir. D. Kizen (Çev.). İstanbul: Jaguar.

Bauman, Z. (2015). Sosyolojik düşünmek. A. Yılmaz (Çev.). İstanbul: Ayrıntı.

Bauman, Z. (2017). Hermenötik ve sosyal bilimler. H. Oruç (Çev.). İstanbul: Ayrıntı.

Bauman, Z. ve Mazzeo R. (2019). Edebiyata övgü. A. E. Pilgir (Çev.). İstanbul: Ayrıntı.

Berktay, F. (2015). Tarihin cinsiyeti. İstanbul: Metis.

Durakbaşa, A. (2014). Halide Edip Türk modernleşmesi ve feminizm. İstanbul: İletişim.

Genç Acar, D. (2018). Social reality and women in the novels of Sabahattin Ali. Tarih ve Günce Atatürk ve Türkiye Cumhuriyeti Tarih Dergisi, 1 (3), 29-50.

Göle, N. (2016). Modern mahrem/medeniyet ve örtünme. İstanbul: Metis.

Kandiyoti, D. (2015). Cariyeler, bacılar, yurttaşlar/kimlikler ve toplumsal dönüşümler. A. Bora vd. (Çev.). İstanbul: Metis.

Korkmaz, R. (1991). Sabahattin Ali -insan ve eser-. Doktora Tezi, Frrat Üniversitesi Sosyal Bilimler Enstitüsü, Elazı̆̆.

Kundera, M. (2014). Roman sanatı. A. Bora (Çev.). İstanbul: Can.

Mengüşoğlu, T. (2017a). İnsan felsefesi. Ankara: Doğu Batı.

Mengüşoğlu, T. (2017b). Felsefeye giriş, Ankara: Doğu Batı. 
What Macide, who was not beaten by “iç̧imizdeki Şeytan” (The Devil inside Us) make us think in terms of gender / A. Şeker (pp. 297-308)

Moran, B. (1999). Edebiyat kuramlarl ve eleştiri. İstanbul: İletişim.

Öztürk, O. (2016). Özerk benlik, kul benlik/biat toplumunun ruhsal kökenleri. İstanbul: Okuyan us.

Parla, J. (2014). Kadın eleştirisi neyi gerçekleştirdi? S. Irzık ve J. Parla (Haz.). Kadınlar dile düşünce/edebiyat ve toplumsal cinsiyet içinde (ss.15-33). İstanbul: İletişim.

Sancar, S. (2014). Türk modernleşmesinin cinsiyeti. İstanbul: İletişim.

Şeker, A. (2020). Edebiyat ve toplumsal cinsiyet. Ankara: Gece.

Tanrıkulu, L. (2018). Çoğuldizge kuramı ışığında Sabahattin Ali’nin İçimizdeki Şeytan adlı romanının incelenmesi. Uluslararası Sosyal Bilimler Eğitimi Dergisi, 4, (1), 27-38.

Timur, T. (2002). Osmanl-Türk romanında tarih, toplum ve kimlik. Ankara: İmge.

Yalçın, A. (2011). Çağdaş Türk romanı 1946-20oo. Ankara: Akçağ. 